
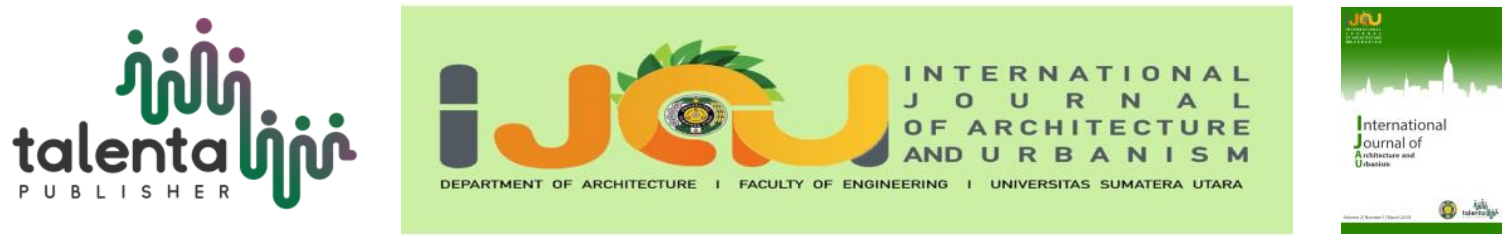

\title{
Business Hotel and Convention Hall Selayang
}

\author{
Imam Faisal Pane ${ }^{1 *}$, James $^{1}$ \\ ${ }^{I}$ Department of Architecture, Universitas Sumatera Utara, Medan, Indonesia
}

\begin{abstract}
Business Hotel and Convention Hall Selayang design start with looks of the business improvement in Medan Ring Road. Medan Ring Road has several new shopping malls and another business center. Medan Selayang District becomes the location of design because it is not located too far from the downtown and the ring road. The site refers to RDTR (Detailed Spatial Plan) Kota Medan 2035 is a commercial area which suitable to design hotel and convention hall as a commercial building. The site is located in a master plan which contains other several commercial buildings; they are a youth center, a museum of art, and shopping mall. The design of this hotel and convention hall have a concept of neo-vernacular architecture which is referred to Malay Architecture in Medan because Medan culture starts from Deli Serdang Empire which has Malay culture and architecture. Therefore, Malay Architecture is rarely visible in Medan City. Malay architecture in Medan is potential to entertain the customers and show to the local communities about the origin of Medan. The hotel design uses modern technology that mix with architecture elements in Malay Architecture. The convention hall design shows big Malay roof to be the point of view. The shape of the buildings is designed from suppression of the site shape.
\end{abstract}

Keyword: hotel, business, convention hall, Selayang

\section{Introduction}

Medan city has 2.122 .804 people with an area of $265.1 \mathrm{~km}^{2}$ and population density of 8008 people $/ \mathrm{km}^{2}$. The development of tourism in Medan can be seen from the number of tourists coming to Medan, according to the Central Bureau of Statistics of North Sumatra Province 2016 (Table 1). Tourist that come to Medan does not only for traveling. Some of them come to Medan for a business trip. Medan is another big city besides Jakarta and Surabaya in Indonesia. To accommodate the tourist, Medan city needs some hotels for the tourist to stay. The target for the hotel is the tourist that have a business trip and also want to travel around Medan.

*Corresponding author at: Department of Architecture, Faculty of Engineering, Universitas Sumatera Utara, Jalan Perpustakaan Gedung J07, Medan 20155, Indonesia

E-mail address: imamfpane@gmail.com 
Table 1. Statistic of Hotel and Tourism Medan

\begin{tabular}{|c|c|c|c|}
\hline \multicolumn{4}{|c|}{ Statistik Hotel \& Pariwisata Medan } \\
\hline Uraian & 2013 & 2014 & 2015 \\
\hline \multicolumn{4}{|l|}{ Akomodasi } \\
\hline Hotel Berbintang & 51 & 55 & 56 \\
\hline Hotel Non Bintang & 144 & 130 & 122 \\
\hline Total & 195 & 185 & 178 \\
\hline \multicolumn{4}{|l|}{ Jumlah Kamar } \\
\hline Hotel Berbintang & 5550 & 6034 & 6308 \\
\hline Hotel Non Bintang & 3644 & 3352 & 3204 \\
\hline Total & 9194 & 9386 & 9512 \\
\hline \multicolumn{4}{|l|}{ Jumlah Tempat Tidur } \\
\hline Hotel Berbintang & 8708 & 9003 & 9300 \\
\hline Hotel Non Bintang & 4453 & 4014 & 3777 \\
\hline Total & 13161 & 13017 & 13077 \\
\hline \multicolumn{4}{|c|}{ Tingkat Hunian Kamar } \\
\hline Hotel Berbintang & 52,98 & 48,99 & 72,27 \\
\hline Hotel Non Bintang & 57,77 & 54,37 & 71,85 \\
\hline Total & 54,29 & 49,97 & 72,20 \\
\hline
\end{tabular}

(Source: Central Bureau of Statistics of North Sumatra Province 2016)

Medan Selayang is one of the sub-districts located in the suburbs, has access to the center of the crowd on Medan City Ring Road and close to the downtown (6 kilometers distance to the Medan mayor's office). Medan City Ring Road has a role in the economic growth of the city because the Medan City Ring Road is very often passed by vehicles from various regions in North Sumatera, whether they want to go to Medan City or pass through Medan. This condition allows a lot of stopover for drivers, several restaurants and hotels to stay in, most hotels are 1 star to 3 stars on Setiabudi Street, and there is Hotel Grandika and Raz Hotel on Dr. Mansyur Street.

Medan Selayang District has land use as settlement, commercial, education, and urban forest. Near the site, there is the University of Sumatera Utara. The existence of this university makes many economies grow well such as boarding houses, rental houses, apartments, restaurants, and convenient stores. In addition to universities, around the site also has several schools that are accommodated by the presence of many housing and residential areas.

Medan is started from a village named Madan under Deli Serdang Empire. Deli Serdang has Malay architecture and so Madan village. Medan has some Malay architecture, but now the famous Malay Building is only Maimoon Palace. Some building still has the ornament of Malay architecture, but it is rarely seen. Around the site of the design, the area is dominant with modern architecture. As the time through people needs something to catch their eye, so this design want to catch their interest from the history and some uniqueness that Medan has.

\section{Literature Review}

Definition of Business Hotel and Convention Hall Selayang is one type of accommodation that 
provides lodging services, food, and recreation, have convention hall and meeting room for meetings between groups of people to discuss or do some event; located in Medan Selayang [5].

The hotel classification is a business hotel. This type of hotel prioritizes business visitors and event organizers who will hold seminars, performances and so on, but the regular hotel guests who want to travel around are welcome too. The main target of the hotel is the businessman, so the support facilities in the bedroom focused on the working area for visitors, while the room still focusing primarily on the comfort of sleep and entertainment for visitors such as television, outside scenery, and good bathroom. Convention hall can be incorporated into one building with the hotel or apart. The main advantage when the convention hall is in different buildings with the hotel is the circulation of visitors who want to stay in the hotel, and the convention hall users can be separate so that the circulation won't be very traffic. The main disadvantage when the convention hall separate from the hotel is the narrowed land [3].

Hotel and convention hall is divided into two resident, namely visitors and managers. Visitors are divided into two: regular visitors (stay in the hotel) or temporary visitors (using the convention hall only or other supporting facilities). The hotel manager is divided into two, frontof-house and back-of-house managers. Front of the house manages direct services to visitors, such as receptionists, security, cleanliness, room service, and concierge. Back of the house manages the services that serve visitors indirectly, such as kitchen, food and beverage managers, utility operations (bathroom, air handling unit, warehouse management, and financial administration management).

Spatial needs are divided into two main areas those are visitor area and management area. The visitor area is divided into four areas: convention hall area, recreation area, reception area and hotel room area. The management area is divided into two main areas: front of the house and back of the house. Front of the house area is divided into eight areas; they are the guest room, public area, lobby area, reception area, guest elevator area, concierge area, convention hall area and parking area. Back of the house is divided into three areas, they are kitchen area, office area manager, service area [1].

The theme applied in this design is neo-vernacular architecture. The theme that is applied is to adjust to the surrounding ambiance and lift back the visual culture around that already faded. Business hotels in the Medan near the center of the city mostly applied colonial and modern themes. Malay buildings that are large enough have rarely been found in Medan. The Malay building in Medan best known is the Istana Maimoon. Medan originally based on Malay culture and architecture. 


\section{Methodology}

The methodology in this design is collecting data from the source and observation of the design location. Collecting data from the source is intended to find hotel design and convention hall data that suitable in Indonesia so that according to the existing standard, newness developed from the analysis then obtained then applied to the concept of design. The analysis is obtained from the observation of the design location, as well as looking for data about the location of the design.

The site selection criteria start with a total area of 30 hectares of the master plan for four commercial functions in the area close to downtown and Medan's ring road. The criteria for location selection are based on the growing Medan economic growth in the ring road of Medan and not too far away with the city center because of the city center still the largest business center. The site is observed by looking at the existing and the rule in Medan City based on RDTR (Detailed Spatial Plan) 2035. The site was decided on Abdul Hakim Road which located in Medan Selayang District. The site is not too far from Medan City Ring Road and downtown. Based on RDTR 2035, the site has a land use as a commercial area, suitable for this design, although the site is surrounded by the settlement. This makes the master plan have to build a lot of buffer and pedestrian for respond the settlement.

The design of location is surrounded by main streets; they are Abdul Hakim Street, Dr. Mansyur Street, and Setiabudi Street (Figure 1). Abdul Hakim Street is the main street for the site, Dr. Mansyur Street is the busiest because it is passed by the vehicles from Setiabudi Street to Jamin Ginting Street and vice versa. Dr. Mansyur also the main street for the University of Sumatera Utara which has busy traffic. Setiabudi Street is crowded by the settlements and shop-houses.

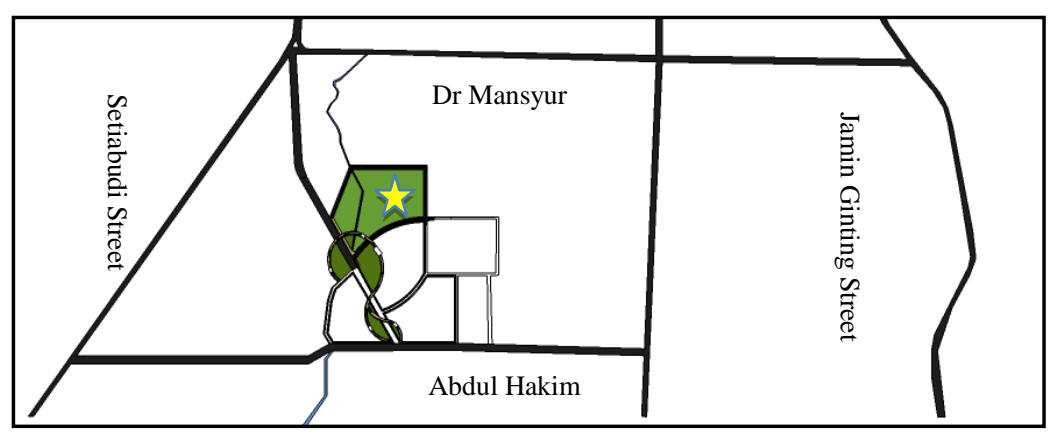

Figure 1. Location of Design

The master plan was designed by the same developer, so the four function inside the master plan is integrated each other by a sky bridge and pedestrian (Figure 2). The master plan is crossed by Selayang River. The main street in the master plan is according to RDTR Medan City 2035 that modified and detailed by the developer. There is some alley to connect to the settlement, and the street is circular to make the traffic ease. 


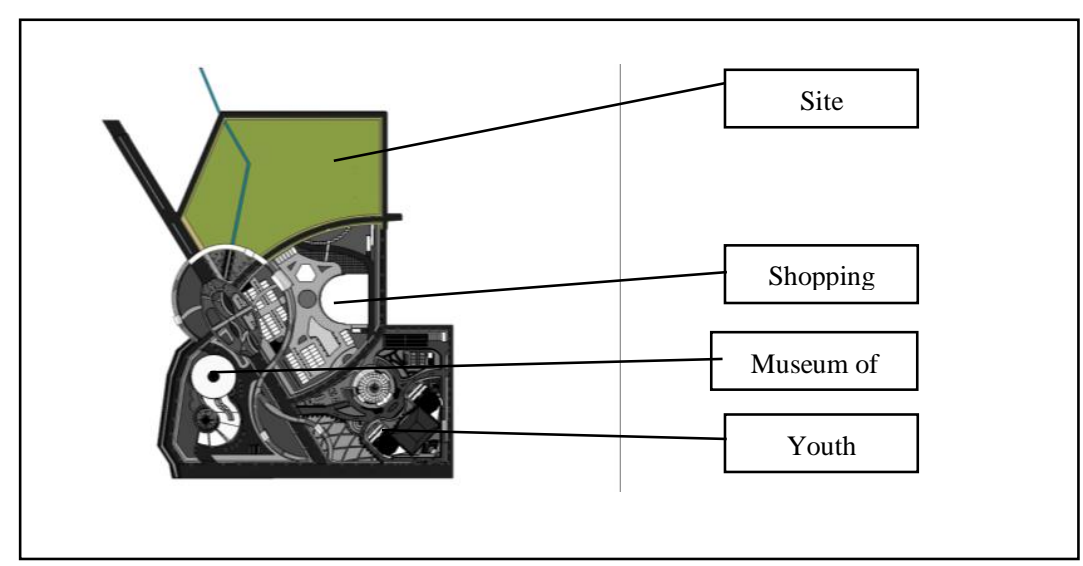

Figure 2. Master Plan

\section{Result and Discussion}

The site is located at Jalan Abdul Hakim, Medan Selayang, Medan. The location of this site is close to the ring road of Medan and Medan city center. The distance from the site to the city center is $6 \mathrm{~km}$, by using the car takes about 30 minutes, while heading to the ring road of Medan takes about 20 minutes by car. The design location also has enough area for the master plan that is 33 hectares. Data according to RDTR (Detailed Spatial Plan) Medan 2035, the location of the design has a commercial land use in the form of commercial areas, with an additional new road connecting Abdul Hakim Road with Dr. Mansyur Road.

The hotel typology used is linear with the circular core in the middle [4]. The convention hall building is separated by consideration of sufficient land area and ease of access from master plan design. The hotel has nine floors and one basement floor. The convention hall has two floors without a basement. The hotel has nine floors due to the analysis of the site which is close to the residents settlement, so the shadow direction of the building does not interfere with the activities of the residents, the maximum floor that can be obtained is nine floors, while the convention hall in accordance with the analysis of space program. The presence of convention hall makes the need for the park is also increased rather than just an ordinary hotel. The use of basement is reduced because it will cost more, and if build a building parking will reduce the image of the hotel because the hotel is surrounded by roads and settlements. The strong image of this design remains on the main path of the master plan.

The Hotel has four types of room; they are suite room, deluxe suite room, premiere suit room, and presidential suite room. The convention hall has a grand ballroom that can separate into two junior convention hall to accommodate little seminar. The shape of the building is completed with site form analysis; there is Selayang River which divides the design site so that the river is set to be the limitation, so the parking area is focused on the small section of the river. For the vegetation, Hotel and Convention Hall Selayang use palm trees to increase the ambiance of tropical climate and for the visual. Some of the land in the site is functioning as a drain for rainwater and for the visual it design to be a tropical garden. 
The application of Neo Vernacular in the building is taken from Malay Architecture, with the uniqueness of columns, windows, doors, and roof. Malay architecture is applied with modern technology in the form of steel reinforcement on columns and beams, and on the door and window using aluminum and wood [2]. A typical Malay roof is applied to a wide span of convention hall using a truss system. The utility and services are on the basement floor of the hotel. The access is from behind the site near the hotel exit. The employee that works in the hotel uses that path to reach the building.

\subsection{Landscape}

The shape of the landscape is like a trapezium with an arc in three sides. The shape of the site is based on the master plan design. There is a focal point which is a garden in the center of the master plan (Figure 3). First of all, the site shape is analyzed with the direction and the suppression of the site. There is a major axis that direct to the master plan focal point. There are two lines that cut the site shape into three area; they are Selayang River and sky-bridge.

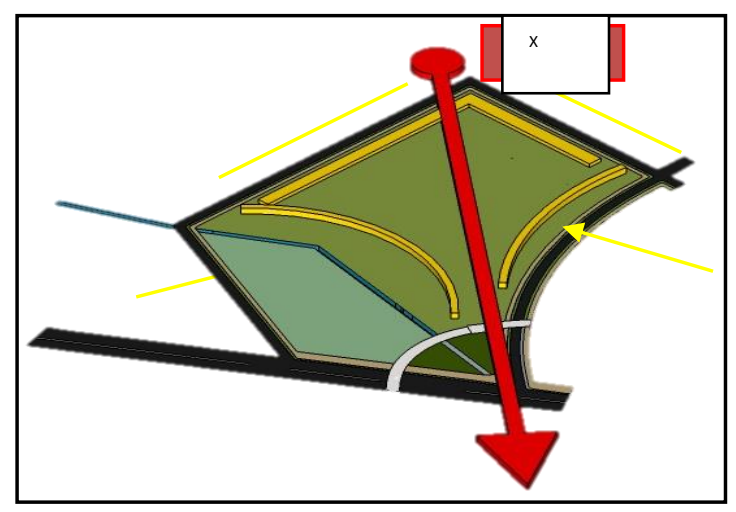

Figure 3. Site Shape Concept

Vehicle circulation in the site divided into two, convention circulation and hotel circulation (Figure 4). The circulation is separate to avoid the traffic inside or outside the site. The entrance of the hotel is using the side street. Hotel circulation has to be simple because not many cars will park, they will often use the drop-off or the entrance hall area. The entrance of the convention hall is on the main street of the master plan. The convention circulation has a direct through a pass, so if the vehicle just wants to drop off or pick up, they can easily exit from the site. The parking lot in the convention is larger than the parking lot in the hotel to accommodate the customers in the convention hall. 


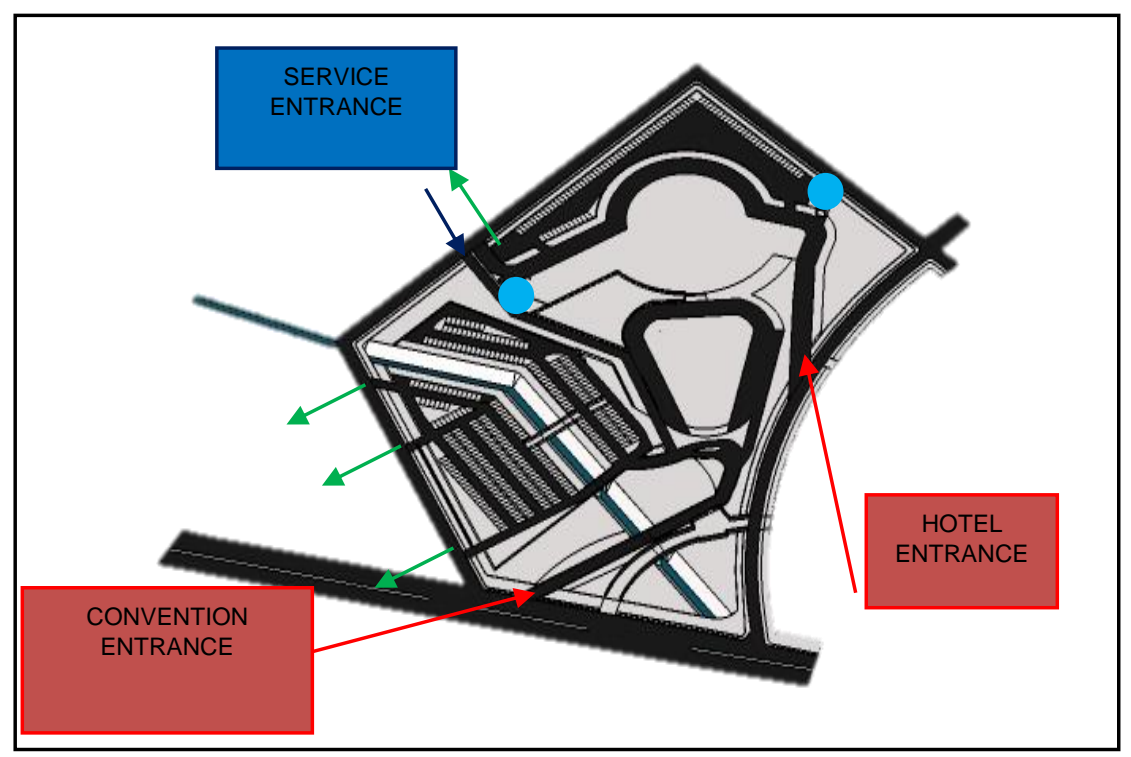

Figure 4. Vehicle Circulation Concept

The service circulation is using the back street. The proportion of service circulation is the smallest. Service circulation is the hotel staff, loading, utility and operational team. The service circulation is built as efficient as possible because they have to serve right the customers at the right time and the right place which the customers can't see the preparation. The customers just have to accept the right service. The vegetation of this design is used palm trees as main trees, then in the parking lot use the lush trees. The vegetation is not just for ambiance but buffers the sound and visual from inside or outside the site (Figure 5). The privacy still needs to protect.

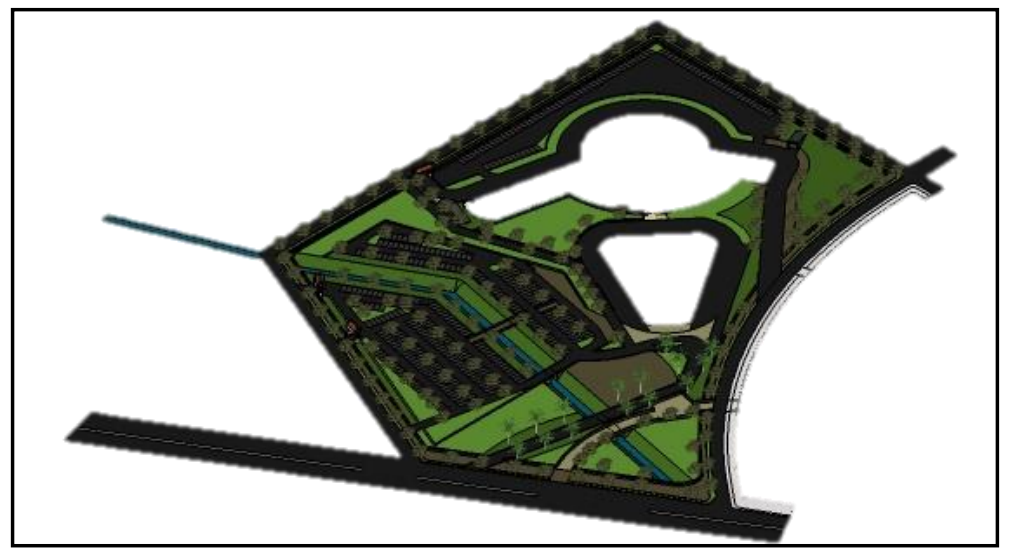

Figure 5. Vegetation Concept

\subsection{Building Mass and Form}

The building mass and form are according to the site form. The suppression and the axis direct the direction of the building. The main façade is directed to the main street in the master plan. The structure of this mass is rigid frame because it is not too complicated and build from piles and beams (Figure 6). Convention hall use space truss structure system, to handle a large amount of space in the grand ballroom. 


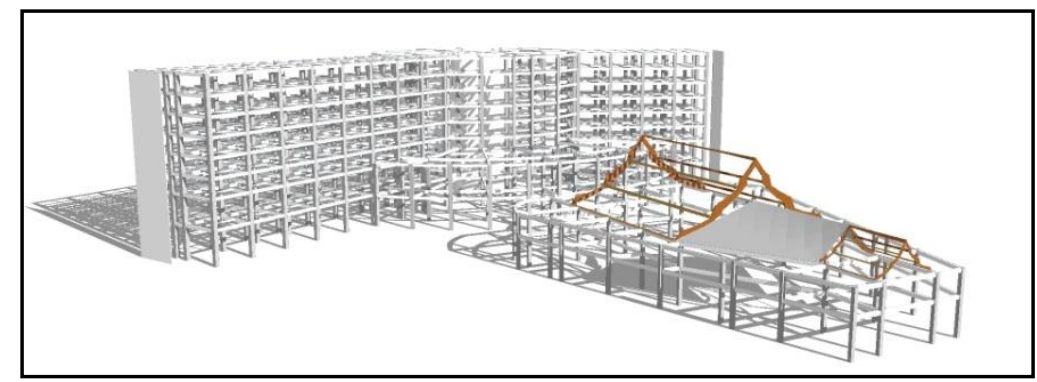

Figure 6. Structure Concept

The façade and form of the building have to suit on site. The color and shape of the building have to be integrated with the environment and the theme of neo-vernacular Malay architecture (Figure 7). The volume of the building mass is based on the programming and analyze. The form of the linear and circular core because of the suppression of the site and the direction of the axis.

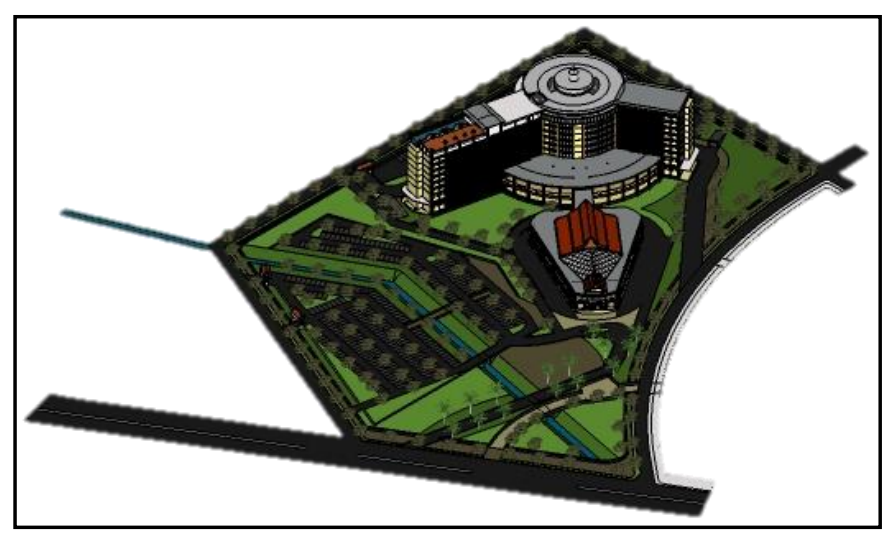

Figure 7. Façade Concept

Business Hotel and Convention Hall Selayang have two main zones those are hotel and convention hall (Figure 8). The hotel has three zones they are service, public area, and guest rooms. Convention hall has four zones they are public area, the grand ballroom, service, and very important person area.

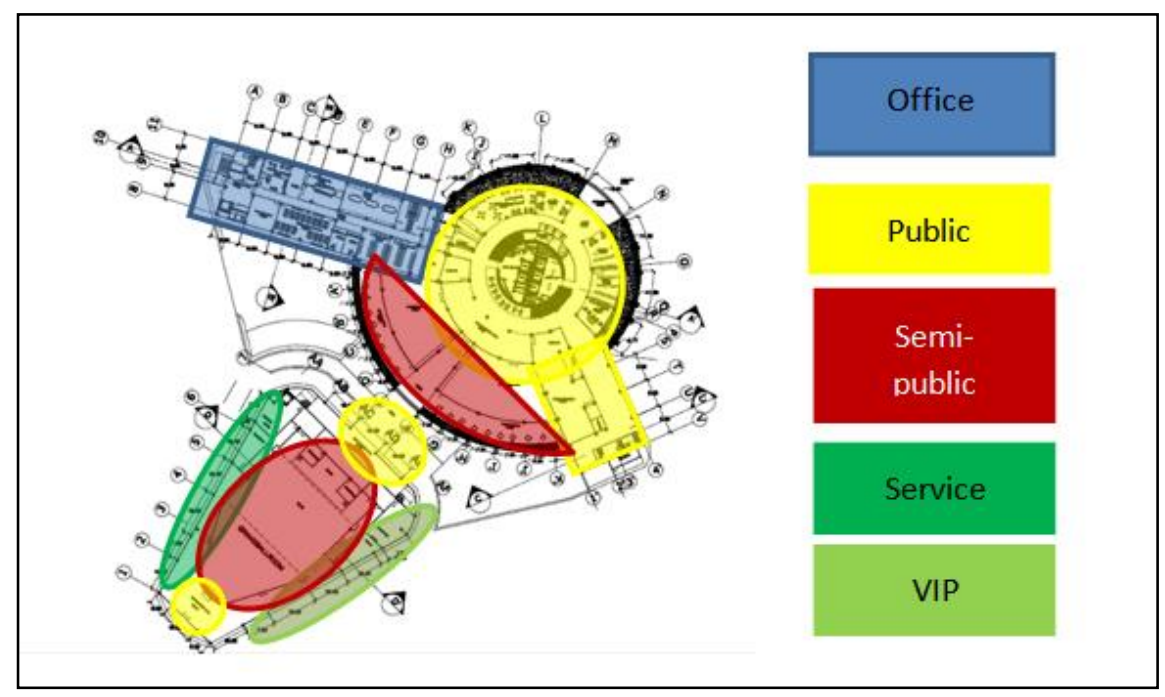

Figure 8. Zoning 
The façade uses a vernacular architecture approach referred to Malay architecture. The building uses the modern structure, but the image of the building is traditional (Figure 9). The building is for commercial and needs to attractive, so the design is a luxury and still calm.

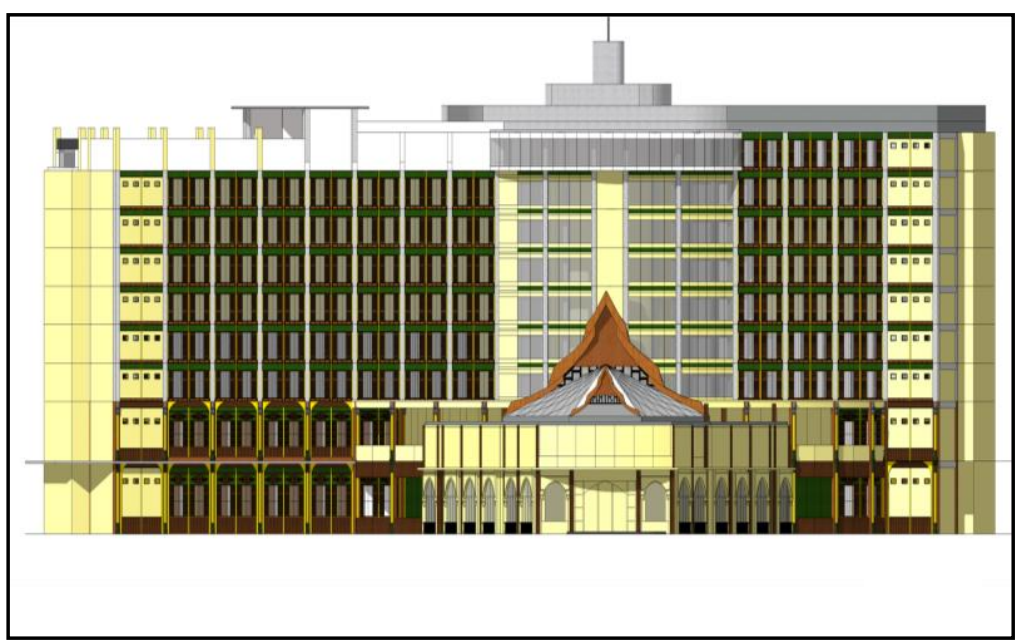

Figure 9. Facade

\section{Conclusion}

Business Hotel and Convention Hall Selayang are located in Medan Selayang District which is near to Ring Road of Medan City, so it is strategic to accommodate the tourists or other customers coming. Businessmen are the main target of this business hotel because of muchgrowing businesses around Medan Selayang Sub-district. The location of the hotel design is also adjacent to the university and some schools to facilitate the activities or events of the educational establishments. Business Hotel and Convention Hall Selayang have meeting facilities in the form of one convention hall, three meeting rooms and two Function Hall, which is equipped with a banquet. Hotel Business and Convention Hall Selayang also has entertainment facilities such as swimming pool, gym, spa and restaurant as recreation and service for guests.

Business Hotel and Convention Hall Selayang as a commercial building designed with the theme of neo-vernacular because it can be a special attraction. Medan City used to have Malay stature derived from the Deli Sultanate, but when colonized by the Dutch. Many buildings that have characteristic of Malay destroyed, so at this time rarely found nuanced Malay buildings around the District of Medan Selayang.

The building of the hotel and the convention hall space is separated because with a large enough land can be utilized for more space for costumers, the open space available is also wide enough for parking and garden as water absorption because the location is crossed by Sungai Selayang, and around the location mostly is the settlement. Parking space provided is wide enough to anticipate congestion outside the area because it will disturb residents around. The land is also integrated with a master plan that containing commercial buildings such as art museums, youth 
center, and shopping mall, combined with a sky bridge and pedestrian. It is expected that with the commercial center in Medan Selayang District, can add economic development in Medan.

The main design to this building is Malay architecture. The façade is focused on the harmonic between traditional and modern, but the structure and the space programming follow the Malay architecture and suit the hotel and convention hall programming. The façade is not just a showcase but need to suitable for the building.

\section{Acknowledgment}

The author grateful to the God for good health and wellbeing that were necessary to complete this journal. The author also expressed his gratitude to Department of Architecture, Universitas Sumatera Utara who provided insight and expertise that greatly assisted the research.

\section{REFERENCES}

[1] J. De Chiara, and J. H. Callender (Eds.). Time-saver standards for building types. New York: McGraw-Hill. 1990.

[2] D. Erdiono. Arsitektur 'Modern'(Neo) Vernakular di Indonesia. Sabua, 3(3). 2012.

[3] D. Littlefield. Metric handbook. Routledge. 2008.

[4] E. Neufert, P. Neufert, and J. Kister. Architects' data. John Wiley \& Sons. 2012.

[5] W. A. Rutes, R. H. Penner and L. Adams. Hotel design, planning, and development. WW Norton \& Company. 2001. 